\title{
China's New Environmental Protection Law and Green Innovation: Evidence from Prefecture-Level Cities
}

\author{
Wen Chen (i) and Ying Wu (iD \\ School of Finance, Southwestern University of Finance and Economics, Chengdu 611130, China \\ Correspondence should be addressed to Wen Chen; chenwen@swufe.edu.cn
}

Received 15 January 2021; Revised 14 April 2021; Accepted 8 May 2021; Published 19 May 2021

Academic Editor: Wei Zhang

Copyright ( $\odot 2021$ Wen Chen and Ying Wu. This is an open access article distributed under the Creative Commons Attribution License, which permits unrestricted use, distribution, and reproduction in any medium, provided the original work is properly cited.

\begin{abstract}
This paper examines the impact of China's new environmental protection law on green innovation. Using a large sample of Chinese prefecture-level cities for the 2010-2016 period and the difference-in-differences (DID) methodology, we provide strong evidence that the new environmental protection law promotes green innovation. This finding is robust to a battery of sensitivity tests. The micromechanism analysis shows that the new environmental protection law can promote green innovation by imposing stricter financial constraints on enterprises in high-pollution industries and increasing their incentives for green innovation to meet green credit requirements. Further, we find that the impact of the new environmental protection law on green innovation is more prominent in prefecture-level cities with a lower level of banking competition and for prefecture-level cities with stronger intellectual property protection. Overall, these findings suggest that the new environmental protection law has played an important role in promoting green innovation in China. To improve the effect of the new environmental protection law on green innovation, the government can consider lowering banking competition and strengthening intellectual property protection.
\end{abstract}

\section{Introduction}

Although China has embraced rapid economic development in the past 40 years, the country also faces serious environmental issues, causing great losses in resident health and economic benefits $[1,2]$. For example, according to the State of Global Air Report 2019, 425 million people were exposed to household air pollution, and 1.2 million Chinese people lost their lives due to air pollution in 2017 (https://www. stateofglobalair.org/). Reducing environmental pollution is receiving increasing attention from policymakers and the academic community [3-9].

Recently, various studies have focused on agricultural and industrial sectors for the estimation of resources and environmental protection [10-15]. Similarly, some studies have determined the environmental performance of the industrial sector [16-21]. In addition, scholars have examined the effect of environmental regulations on environmental protection [6-9]. However, green innovation is regarded as the key to resolving environmental issues
$[22,23]$. Green innovation refers to hardware or software innovations related to green products or processes, including technological innovations involved in energy conservation, waste recycling, pollution prevention, green product design, and environmental management, leading to the coordination of economic development and environmental protection [24].

Previous studies have found that environmental regulations play an important role in green innovation [25-29]. For example, using data on five manufacturing sectors in the European Union from 1996 to 2007, Costantini and Mazzanti tested the Porter hypothesis and found that environmental policies can promote environmental innovation efforts and foster green exports [26]. Shen et al. tested the impact of different environmental policies on regional green innovation and found that pollution charges can promote green innovation and that, in general, carbon emissions trading has an insignificant effect on green innovation in provinces [27]. Calel and Antoine examined the impact of the European Union Emissions Trade Scheme on 
technological change and noted that environmental policy has a limited impact on low-carbon patents [28]. Using publicly listed firms in China from 2003 to 2015, Cui et al. investigated whether carbon emissions trading in China had affected low-carbon innovation and found that the policy had a significant and positive impact on low-carbon innovation [29]. Although these studies examined the effects of different government regulations on green innovation, we know little about whether the environmental protection law, the most critical environmental regulation, has a positive impact on green innovation. The new environmental protection law in China provides a chance to investigate this issue.

China enacted its environmental protection law, which contains 6 chapters and 47 articles, in 1989. Although the environmental protection law was issued, environmental protection was weak in China because China's top priority was economic development [30]. The government, without prioritizing environmental protection, allowed extensive economic growth to dominate China's economy. Consequently, China now faces more serious environmental pollution issues, thus causing considerable losses to human health. Environmental protection became increasingly important to Chinese economic development, causing the government to revise its environmental protection law.

Revisions to the environmental protection law were proposed from 1995 to 2011. The Chinese government decided to revise the environmental protection law in 2011. The first draft issued by China's National People's Congress (NPC) Standing Committee encountered resistance and was not passed because it only included minor amendments (the draft followed a "limited revision" principle, and many internationally established practices and concepts, such as sustainable development, strategic environmental impact assessment, market-based instruments, environmental rights and interests, and public litigation, were not included). The $18^{\text {th }}$ CPC National Congress in 2012 emphasized ecological civilization as the basic direction of national construction, which promoted the revision of the environmental law. The second draft and third draft were submitted after consulting from experts, scholars, local environmental protection departments, entrepreneurs, and other environmental interest groups in 2013. Finally, the NPC Standing Committee passed the revised law in 2014, and the new environmental protection law went into effect on January 1, 2015. The new environmental protection law includes 7 chapters and 70 articles, which represent major revisions of those in the previous environmental protection law $[30,31]$ and have had a substantial effect on Chinese environmental protection.

The effect of the new environmental protection law on economic society has attracted attention from scholars [30, 32-34]. For example, Zhang et al. reviewed the enactment of the new environmental protection law and pointed out some problems with it [30]. Liu et al. showed that the new environmental protection law makes Chinese firms face more public pressure and higher operating costs, resulting in a significant drop in the financing capacity of heavily pollution firms [32]. Applying the theory of planned behavior, Chen et al. showed that the new environmental protection law has a positive effect on the relationship between environmental intentions and the public's environmental behaviors [33]. Cai and Ye found that the new environmental protection law has a negative effect on enterprises' total factor productivity [34]. To our limited knowledge, however, no existing studies have systematically explored the new environmental protection law on green innovation in Chinese prefecture-level cities. Our paper helps fill this gap by examining the impact of the new environmental protection law on green innovation in Chinese prefecture-level cities.

We use the enactment of the new environmental protection law as an exogenous shock to examine the impact of government environmental regulation on green innovation. More specifically, we test whether the new environmental protection law provides a positive incentive for green innovation, how the new environmental protection law impacts green innovation, and whether the relationship between the new environmental protection law and green innovation can be affected by other factors.

Using unbalanced panel data on Chinese prefecture-level cities from 2010 to 2016 and a difference-in-differences (DID) methodology, we investigate the causal effect of China's new environmental protection law on green innovation. We use prefecture-level cities as research objects and measure green innovation by green patents. The law was enacted by the central government and affects all prefecturelevel cities in China; therefore, our research is unaffected by sample selection bias. Although all prefecture-level cities are affected by the law, the exogenous shock to green innovation varies according to the environmental quality of the different prefecture-level cities. The lower the environmental quality is in a prefecture-level city, the greater the influence of the new environmental law is. We document evidence that the new environmental protection law has stimulated green innovation in prefecture-level cities.

To investigate the microchannel through which the new environmental protection law affects green innovation, we use data on listed firms to study the value of green innovation for firms from the financial constraint perspective. The new environmental protection law is found to aggregate the financial constraints on firms that belong to highpollution industries. However, firms' financial constraints can be effectively alleviated by participating in green innovation. This finding shows that the new environmental protection law can enhance firms' green innovation incentives by affecting firms' financial constraints. In addition, we discuss how to enhance the positive impact of the new environmental law on green innovation.

Banking competition affects innovation $[35,36]$. Because a firm's incentive to engage in green innovation is to offset the negative effect of the financial constraints caused by the introduction of the new environmental law, a lower level of banking competition improves the market power of banks, thus strengthening the negative effects of the new environmental protection law on the financial constraints of firms in high-pollution industries and increasing their incentives to invest in green innovations. Our empirical results 
support the view that the positive association between the new environmental protection law and green innovation is more prominent in regions with lower levels of banking competition. Moreover, prior studies have argued that intellectual property protection is conducive to innovation [37]. Better intellectual property protection can improve the marginal benefits of engaging in innovation, thus encouraging innovation. We find that intellectual property protection strengthens the effect of the new environmental protection law on green innovation.

By investigating the micromechanism underlying the effect of the new environmental protection law on green innovation and the moderating effects of the banking structure and intellectual property protection on the relationship between the new environmental protection law and green innovation, this paper contributes to the current literature in three dimensions.

First, this paper expands the research on the impact of environmental regulation on green innovation. Prior literature mainly focused on the government regulation of green innovation in developed countries $[26,28]$ and provided less evidence about whether the changing law could impact green innovation. Our research examines the impact of the Chinese new environmental protection law on green innovation and finds that the stringency of environmental protection can promote green innovation, which can help policymakers and scholars to better understand the role of government regulation in green innovation.

Second, this paper enriches the research on green innovation. The literature on green innovation concentrates on the impacts of green innovation, such as energy efficiency [38], environmental quality [39], employment [40], firm competence [41], and firm performance [42]. Scholars also have examined which factors affect green innovation, such as customer demand [43], political capital [44], loans [22], corporate governance [45], and environmental regulation [26]. This paper finds that green innovation can be stimulated by the implementation of new environmental laws, enriching research in the field of green innovation. In addition, we find that intellectual property protection strengthens the effect of the new environmental protection law on stimulating green innovation.

Finally, our paper enriches the literature on the effect of the banking structure on technological change. As the source of most external financial resources for enterprises worldwide [46], the banking sector plays an important role in innovation [35, 36]. More competition in the banking sector can reduce the market power of banks, increase firms' access to finance $[47,48]$, and alleviate firms' financial constraints [48]. As some scholars have pointed out, more competition in the banking sector can promote innovation [49]. However, this paper finds that fiercer competition among banks may harm the new environmental law's effect on promoting green innovation, as the environmental requirement for green credits can be relaxed when banks compete seriously for borrowers. Given enterprises' investments in green innovation to offset the negative effect of the financial constraints caused by the introduction of the new environmental law, it is believed that limiting banking competition may be crucial for realizing the positive effect of the new environmental law on green innovation.

The rest of this paper is organized as follows. We develop our hypothesis in Section 2; describe the sample selection procedure, variables, and empirical methodology in Section 3; present the empirical results and robustness tests in Section 4; discuss the micromechanisms in Section 5; provide further discussion in Section 6; and conclude this paper in Section 7.

\section{Hypothesis Development}

The new environmental protection law promotes green innovation in the following ways. First, the law changed the focus of economic development in China and strengthened environmental protection as a basic national policy. If an enterprise does not engage in green innovation, it will be difficult for it to survive in the future. Article 1 of the law mandates that the purposes of the law are to protect public health, promote ecological civilization, and promote the sustainable development of the economy and of society. Article 4 states that environmental protection is a basic national policy for the first time. This means that the Chinese government has given up the model of economic development at the cost of environmental pollution, and China's economy has embarked on a path of sustainable development. In this context, enterprises with higher energy consumption and higher pollution must face the fact that they might not survive. For example, according to the Environmental Status Bulletin of Henan Province in 2017, the province shut down 83000 enterprises with high levels of pollution to improve air quality. Therefore, enterprises with higher energy consumption and higher pollution must develop green innovations for survival.

Second, the government has expanded its penalties for enterprises that generate environmental pollution and its support for the environmentally friendly development of enterprises. In terms of environmental punishments, article 53 states that the environmental protection department shall record information on the environmental violations of enterprises in social credit files and promptly announce the list of violators to society. This article affects enterprise development because banks, the most important source of external capital to firms around the world [46], consider environmental credit information (the Ministry of Environmental Protection, together with the National Development and Reform Commission, the People's Bank of China, and the China Banking Regulatory Commission, issued the "enterprise environmental credit evaluation measures (for trial implementation)" in 2013; this means that the environmental credits of enterprises are considered when enterprises apply for bank loans). Polluting enterprises face higher financing costs and have a lower ability to receive financing after the enactment of the new environmental protection law [32]. In contrast, if an enterprise develops a green innovation to protect the environment, it can obtain green credits at a low cost. In addition, article 3 of the law mandates that if enterprises without a discharge permit refuse to execute environmental protection measures, the 
judicial authority can detain the management in charge, meaning that the price of environmental pollution is higher when enterprises violate environmental protection rules. This might give management an incentive to develop green innovations to avoid possible criminal penalties. Moreover, the Chinese government has also provided incentives for enterprises. Article 22 of the law states that if enterprises further reduce their pollution emissions and their discharge of pollutants meets statutory rules, the Chinese government will use policies and measures, including finance, taxation, price adjustments, and government procurement, to support them. Huang et al. found that government support is conducive to green innovation [22].

Finally, the new environmental protection law also improved people's demand for environmentally friendly products. Article 9 of the law mandates that administrative education departments and schools incorporate environmental protection knowledge into school educational content and cultivate students' awareness of environmental issues to improve people's concern for the environment and increase preferences for environmentally friendly products. The demands of environmentally friendly people are an important factor that motivates firms to engage in green innovation [50]. Therefore, to acquire a more positive ecological reputation and satisfy the increasing demand for environmentally friendly products, enterprises have greater incentives to conduct green innovation.

In summary, the new environmental protection law can promote green innovation by changing the old economic development model, expanding the penalties and support for enterprises' different environmental behaviors, and increasing people's demand for environmentally friendly products. Thus, we propose the following hypothesis.

Hypothesis. The new environmental protection law has a positive effect on green innovation.

\section{Sample and Empirical Methodology}

3.1. Sample. Although many studies focus on the green innovation of listed firms, green innovation data from prefecture-level cities can comprehensively reflect the impact of the new environmental protection law on green innovation because the IPO market in China is strictly regulated, allowing only a small proportion of firms to list successfully [51]. Many firms are private enterprises. The data on green innovation in prefecture-level cities contain the green innovation outputs of all innovation parties. Therefore, using prefecture-level cities as research objects can better represent the impact of the new environmental protection law on green innovation.

To construct our sample, we start with all Chinese prefecture-level cities during 2010-2016. The macrodata are collected from the China Research Data Service (CNRDS) database, which provides detailed economic statistics on prefecture-level cities. Green patent data are collected from the Chinese National Intellectual Property Administration. Because there is no specific definition of green innovation, following Li et al. [52], we regard a patent as being for a green innovation when the introduction of the patent includes the following Chinese keywords: green, environmental, ecology, sustainable, low carbon, clean, cycling, energy-saving, and emission reduction. Environmental quality data are collected from the Columbia University Social and Economic Data Center, which provides environmental data for China from 1998 to 2016. Then, we exclude city-year observations with missing information for any variable. Our final sample includes 1798 city-year observations representing 266 prefecture-level cities (according to Chinese Nation Bureau of Statistics, there are 293 prefecture-level cities in 2019). We winsorize all continuous variables at the $1 \%$ and $99 \%$ levels to mitigate the effects of outliers.

3.2. Measuring Green Innovation. Following Sun et al. [38], Zhang et al. [42], Amore and Bennedsen [45], and Li et al. [52], we use patent data as a measure of green innovation. There are three types of patents in China: invention patents, utility model patents, and external design patents. Invention patents have three characteristics: inventiveness, novelty, and practical applicability. Thus, innovations under invention patents are the most novel. Utility model patents require innovation in the application of a product. External design patents are only for external innovations. Therefore, external design patents are not issued for green innovations, and green innovations are patented under invention patents and utility model patents only [42]. Additionally, owing to the lag between a patent being applied for and being granted, the timing of the patent application better captures the actual timing of the innovation [53]. Therefore, we use the application date of green patents to measure green innovation. Specifically, we use the number of green patents divided by the number of total patents in prefecture-level cities to measure green innovation (Ginnovation).

3.3. Methodology. The enactment of the new environmental protection law was an exogenous shock to green innovation in prefecture-level cities; thus, we use the difference-in-differences methodology to test whether this new environmental law has promoted green innovation. Specifically, we investigate the differences in green innovation in prefecture-level cities that are more greatly affected by the new environmental protection law before and after the law ("Treatment" group) compared to the same differences in prefecture-level cities that are less affected ("Control" group).

Due to the new environmental protection law being enforced in all Chinese prefecture-level cities, we need to divide the prefecture-level cities into two groups: "Treatment" and "Control". Because air pollution is the main environmental issue, we use the $\mathrm{PM}_{2.5}$ concentration to measure environmental quality. We define a prefecture-level city as being in the "Treatment" group when its mean value of $\mathrm{PM}_{2.5}$ is higher than the mean value of environmental quality across all prefecture-level cities before 2015. This approach is taken because a prefecture-level city with heavier environmental issues should be more greatly affected after the enactment of the new environmental protection law. 
Simultaneously, a prefecture-level city is defined as being in the "Control" group when its mean value of $\mathrm{PM}_{2.5}$ is lower than the mean value of environmental quality across all prefecture-level cities before 2015. Then, we use the following model to examine the impact of the new environmental protection law on air pollution:

$$
\begin{aligned}
\text { Ginnovation }_{i, t}= & \beta_{0}+\beta_{1} \text { Treat }_{i} \times \text { Post }_{t}+\beta_{2} A G D P_{i, t}+\beta_{3} \times \text { Struct }_{i, t}+\beta_{4} \times F D I_{i, t}+\beta_{5} \text { Science }_{i, t} \\
& +\beta_{6} \times \text { Industry }_{i, t}+\beta_{7} \times P O P_{i, t}+\beta_{8} P M 25_{i, t}+\mu_{i}+v_{t}+\varepsilon_{i, t} .
\end{aligned}
$$

where $i$ and $t$ represent prefecture-level cities and years, respectively. Ginnovation denotes green innovation in a prefecture-level city. Treat is an indicator variable that equals 1 when a prefecture-level city belongs to the "Treatment" group and 0 otherwise. Post is also an indicator variable. Post is set to 1 after 2014 and 0 otherwise, because the new environmental protection law came into effect on January 1 , 2015. We also control for other factors that affect air pollution in prefecture-level cities. Specifically, we include the natural logarithm of GDP per capita (AGDP), tertiary sector output divided by secondary sector output (Struct), foreign direct investment divided by GDP (FDI) (foreign direct investment is measured in dollars in the database; we convert dollars into RMB by using the annual average exchange rate), the natural logarithm of government subsidies on science and technology (Science), the natural logarithm of the number of industrial enterprises (Industry), the natural logarithm of the population (POP), and the natural logarithm of the $\mathrm{PM}_{2.5}$ concentration (PM25). We also include prefecture-level city fixed effects $\left(\mu_{i}\right)$ to control for unobservable time-invariant prefecture-level city characteristics and year fixed effects $\left(v_{t}\right)$ to control for common time trends. We do not include Post $_{t}$ and Treat ${ }_{i}$ in our model individually because these variables are absorbed by the year fixed effects and prefecture-level city effects. The coefficient of interest is $\beta_{1}$. According to our hypothesis, we expect $\beta_{1}$ to be positive. All variables are defined in Table 1.

\section{Empirical Tests and Results}

4.1. Descriptive Statistics. Panel A of Table 2 reports the summary statistics for the variables used in our analysis. As shown in Panel A, green innovation's mean and median values are 0.0278 and 0.0240 , respectively. The mean value of Treat is 0.4667 , suggesting that $46.67 \%$ of samples belong to the "Treatment" group. Panel B reports the correlation coefficient between variables. The correlation between green innovation and the other variables is not high, indicating that multicollinearity is not a serious problem.

4.2. Main Results. Table 3 reports the results from estimating model (1). In column 1, we regress the dependent variable on the interaction term Treat $\times$ Post only. The coefficient on Treat $\times$ Post is positive and statistically significant at the $1 \%$ level, which preliminarily shows that the new environmental protection law promotes green innovation. In column 2, we control for economic development (AGDP), foreign direct investment $(F D I)$, and government expenditure on science and technology subsidies (Science); the coefficient on Treat $\times$ Post is significant and positive. In column 3 , we control for all variables, and the coefficient on Treat $\times$ Post is positive and statistically significant at the $1 \%$ level, supporting our hypothesis that the new environmental protection law has a positive effect on green innovation.

In terms of control variables, we find that the coefficient of Science is significant and positive in column 3, consistent with the fact that the government provides funds for enterprises to implement research and development, reducing the financial stress on enterprises. In addition, the regression result for PM25 is positive and statistically significant at the $10 \%$ level, suggesting that environmental issues force prefecture-level cities to engage in green innovation.

4.3. Robustness Tests. In this subsection, we run several robustness tests. First, the DID methodology is based on the parallel trend assumption, suggesting that the trends in green innovation in the "Treatment" group and the "Control" group have no significant differences before the enactment of the new environmental protection law. Following $\mathrm{Xu}$ et al. [54], we test the parallel trends assumption by replacing the Post indicator with several cohort-year dummy variables in model (1): Year2011, Year2012, Year2013, Year2014, Year2015, and Year2016. If the parallel trends assumption is satisfied, the interaction terms between Treat and Year2011, Year2012, Year2013, and Year2014 should not be significant. As shown in column 1 of Table 4, we find that the parallel trends assumption is satisfied. In addition, the interaction terms between Treat and Year2015 and Year2016 are significant and positive, indicating an overall persistent increase in green innovation after the enactment of the new environmental protection law.

In addition, to ensure that the "Treatment" group and the "Control" group are comparable, we employ propensity score matching (PSM) to match the groups. The matching procedure relies on the one-to-one nearest neighbor matching of cities by propensity score without replacement; the propensity scores are estimated by a logit regression of Treat on a set of control variables that include economic development $(A G D P)$, foreign direct investment $(F D I)$, and government expenditure on science and technology subsidies (Science). Then, we use model (1) to investigate the impact of the new environmental protection law on green innovation. As shown in column 2 of Table 4, the coefficient on Treat $\times$ Post is positive and statistically significant, which is consistent with our hypothesis. 
TABLE 1: Variables and definitions.

\begin{tabular}{|c|c|}
\hline Variable & Definition \\
\hline Ginnovation & The share of green patents in total patents within a prefecture-level city \\
\hline Treat & $\begin{array}{l}\text { A dummy variable that equals } 1 \text { if the mean value of PM2.5 in the prefecture-level city is greater than the mean value of } \\
\text { environmental quality across all prefecture-level cities before } 2015 \text { and } 0 \text { otherwise }\end{array}$ \\
\hline Post & A dummy variable that is 1 after 2014 and 0 otherwise \\
\hline AGDP & The natural logarithm of GDP per capita \\
\hline FDI & Foreign direct investment divided by GDP \\
\hline Struct & Tertiary sector output divided by secondary sector output \\
\hline Science & The natural logarithm of government subsidies for science and technology \\
\hline Industry & The natural logarithm of the number of industrial enterprises \\
\hline POP & The natural logarithm of the population \\
\hline PM25 & The natural logarithm of the $\mathrm{PM}_{2.5}$ concentration \\
\hline Ginnovation 1 & The number of green patents granted divided by the number of all patents granted \\
\hline Town & Area of urban construction land divided by the area of the prefecture-level city \\
\hline HHI & The definition is shown in model 2 \\
\hline IPP & The natural logarithm of the number of first instances of intellectual property infringement in a province \\
\hline SA & $-0.737 \times \operatorname{Ln}($ Assets $)+0.043 \times \operatorname{Ln}(\text { Asset })^{2}-0.04 \times$ Firm age \\
\hline Treatt & A dummy variable that is 1 when an enterprise belongs to a heavily polluting industry and 0 otherwise \\
\hline Size & The natural logarithm of total assets \\
\hline Lev & Total debt divided by total assets \\
\hline Tangi & Tangible assets divided by total asset \\
\hline ROA & Net profit divided by total assets \\
\hline Age & The natural logarithm of firm's age \\
\hline SOE & A dummy variable that is 1 when an enterprises is controlled by government and 0 otherwise \\
\hline TOP1 & The number of shares held by the controlling shareholder divided by the number of all shares \\
\hline Duality & A dummy variable that is 1 if the CEO and chair of the board are not separate and 0 otherwise \\
\hline
\end{tabular}

TABLE 2: Summary statistics.

\begin{tabular}{|c|c|c|c|c|c|c|c|c|}
\hline \multicolumn{9}{|l|}{ Panel A } \\
\hline Variable & $N$ & Mean & Std & Min & Median & Max & & \\
\hline Ginnovation & 1798 & 0.0278 & 0.0183 & 0.0018 & 0.0240 & 0.1051 & & \\
\hline Treat & 1798 & 0.4667 & 0.0000 & 1.0000 & 1.0000 & 1.0000 & & \\
\hline AGDP & 1798 & 10.5683 & 0.5652 & 9.3238 & 10.5298 & 12.0075 & & \\
\hline FDI & 1798 & 0.0182 & 0.0161 & 0.0002 & 0.0135 & 0.0721 & & \\
\hline Struct & 1798 & 37.7214 & 8.9673 & 11.4700 & 36.7750 & 76.3500 & & \\
\hline Science & 1798 & 10.1692 & 1.1721 & 7.7102 & 10.0353 & 13.4326 & & \\
\hline Industry & 1798 & 6.6649 & 0.9782 & 4.3577 & 6.6425 & 8.8969 & & \\
\hline POP & 1798 & 5.904 & 0.616 & 4.304 & 5.945 & 7.063 & & \\
\hline PM25 & 1798 & 3.5046 & 0.4818 & 1.9671 & 3.5327 & 4.3081 & & \\
\hline \multicolumn{9}{|l|}{ Panel B } \\
\hline & Ginnovation & AGDP & FDI & Struct & Science & Industry & POP & PM2.5 \\
\hline Ginnovation & 1 & & & & & & & \\
\hline AGDP & $0.135 * *$ & 1 & & & & & & \\
\hline FDI & 0.021 & $0.322 * *$ & 1 & & & & & \\
\hline Struct & $0.184 * *$ & $0.346 * *$ & $0.181 * *$ & 1 & & & & \\
\hline Science & $0.084 * *$ & $0.642 * *$ & $0.393 * *$ & $0.431 * *$ & 1 & & & \\
\hline Industry & $-0.092 * *$ & $0.431 * *$ & $0.334 * *$ & $0.195 * *$ & $0.748 * *$ & 1 & & \\
\hline POP & 0.023 & $-0.180 * *$ & 0.002 & $0.074 * *$ & $0.390 * *$ & $0.598 * *$ & 1 & \\
\hline PM25 & -0.021 & 0.032 & $0.260 * *$ & $-0.095 * *$ & $0.265 * *$ & $0.502 * *$ & $0.425 * *$ & 1 \\
\hline
\end{tabular}

$*, * *$, and $* * *$ indicate statistical significance at the $10 \%, 5 \%$, and $1 \%$ levels, respectively. All variables are defined in Table 1 .

The number of patents granted is also used to measure innovation [55]. Therefore, we replace the original measure of green innovation with this measure. Specifically, we use the number of green patents granted divided by the number of all patents granted in a prefecture-level city to measure green innovation (Ginnovation 1). In column 3 of Table 4, the coefficient on Treat $\times$ Post is positive and statistically significant at the 5\% level, suggesting that the new environmental protection law is conducive to green innovation.

Bian et al. [56] found that urbanization is an important factor that affects regional innovation. Thus, we further control for the effect of urbanization on green innovation [56]. Following Bian et al. [56], we use the area of urban construction land divided by the area of the prefecture-level 
TABLE 3: The impact of the new environmental protection law on green innovation.

\begin{tabular}{lccc}
\hline & $(1)$ & $(2)$ & $(3)$ \\
& Ginnovation & Ginnovation & Ginnovation \\
\hline \multirow{2}{*}{ Treat $\times$ Post } & $0.0044 * * *$ & $0.0046 * * *$ & $0.0049 * * *$ \\
AGDP & $(0.0014)$ & $(0.0014)$ & 0.0014 \\
& & -0.0052 & -0.0032 \\
FDI & & $(0.0034)$ & 0.0035 \\
& & 0.0111 & 0.0316 \\
Struct & & $(0.0411)$ & 0.0425 \\
& & 0.0002 & 0.0001 \\
Science & & $(0.0002)$ & 0.0002 \\
& & 0.0011 & $0.0017 *$ \\
Industry & & $(0.0009)$ & 0.001 \\
& & & $-0.0038 *$ \\
POP & & & 0.0022 \\
& & & -0.0039 \\
PM25 & & & 0.0068 \\
& & & $0.0054 *$ \\
Constant & $0.0259 * * *$ & $0.0630 *$ & 0.003 \\
City FE & $(0.0008)$ & $(0.0365)$ & 0.0673 \\
Year FE & Yes & Yes & 0.0579 \\
$N$ & Yes & Yes & Yes \\
$R^{2}$ & 1798 & 1798 & Yes \\
\hline & 0.0235 & 0.0270 & 0.0318 \\
\hline
\end{tabular}

Robust standard errors are presented in parentheses. $*, * *$, and $* * *$ indicate statistical significance at the $10 \%, 5 \%$, and $1 \%$ levels, respectively.

city to measure urbanization (Town). As shown in column 4 of Table 4 , the coefficient on Treat $\times$ Post is positive and statistically significant, which is consistent with the finding in column 3 of Table 3.

Finally, we adjust the time frame of our analysis. We exclude observations from before 2013 to maintain balance in the number of years before and after the enactment of the law because the new environmental protection law came into effect in 2015. The results are presented in column 5 of Table 4, and the coefficient on Treat $\times$ Post is positive and significant, which is consistent with our hypothesis.

\section{Mechanism Tests}

In Section 2 of this paper, we pointed out that the new environmental protection law promotes green innovation by changing the old economic development model, expanding the penalties and support for enterprises' environmental behavior, and increasing people's demand for environmentally friendly products. However, the data from prefecture-level cities do not include the indicators needed to measure these possible mechanisms. Therefore, we use data from the Chinese listed firms to test the possible economic mechanisms through which the new environmental protection law affects green innovation.

The new environmental protection law mandates that the environmental protection department record the environmental violation information of enterprises in social credit files and promptly announce the list of violators to society (article 53 of the law). Moreover, the Chinese government requests banks to consider the environmental information of enterprises. If an enterprise belongs to a heavily polluting industry, that enterprise faces larger financial constraints. Furthermore, an enterprise in a heavily polluting industry can alleviate its financial constraints by developing green innovations to meet the green credit requirements of banks. Thus, we examine the economic mechanism through which the new environmental protection law affects green innovation by investigating the changes in listed firms' financial constraints.

We collect financial data on Chinese A share firms during 2010-2018 from the China Securities Market and Accounting Research (CSMAR) database. In addition, we collect information on the green innovations of listed firms from the Chinese National Intellectual Property Administration. Then, we exclude financial service firms. To mitigate the effects of outliers, we also winsorize all continuous variables at the $1 \%$ and $99 \%$ levels.

We use the DID methodology to measure the impact of the new environmental protection law on listed firms' financial constraints. The model is set as follows:

$$
\begin{aligned}
\text { SA }_{i, t} & =\gamma_{0}+\gamma_{1} \text { Treatt }_{i} \times \text { Post }_{t}+\gamma_{2} \text { Treatt }_{i}+\gamma_{3} \text { Post }_{t}+\gamma_{4} \text { Size }_{i, t}+\gamma_{5} \times \text { Lev }_{i, t}+\gamma_{6} \times \text { Tangi }_{i, t} \\
& +\gamma_{7} \text { Roa }_{i, t}+\gamma_{8} \times \text { Age }_{i, t}+\gamma_{9} \times \text { SOE }_{i, t}+\gamma_{10} \text { Top }_{i, t}+\gamma_{11} \text { Dualit }_{i, t}+\delta_{i}+v_{t}+\varepsilon_{i, t}, \\
\text { SA }_{i, t} & =\gamma_{0}+\gamma_{1} \text { Treatt }_{i} \times \text { Post }_{t} \times \text { Ginnovation }_{i, t}+\gamma_{2} \text { Treatt }_{i} \times \text { Ginnovation }_{t}+\gamma_{3} \text { Post }_{t} \times \text { Ginnovation }_{i, t}+\gamma_{4} \text { Ginnovation }_{i, t} \\
& +\gamma_{6} \text { Size }_{i, t}+\gamma_{7} \times \text { Lev }_{i, t}+\gamma_{8} \times \text { Tangi }_{i, t}+\gamma_{9} \text { Roa }_{i, t}+\gamma_{10} \times \text { Age }_{i, t}+\gamma_{11} \times \text { SOE }_{i, t}+\gamma_{12} \text { Top }_{i, t}+\delta_{i}+v_{t}+\varepsilon_{i, t},
\end{aligned}
$$

where $i$ and $t$ represent the firm and year, respectively. SA denotes financial constraints. We calculate the SA index values proposed by Hadlock and Pierce [57] to measure financial constraints (the index is defined as $-0.737 \times \operatorname{Ln}$ (Assets) $+0.043 \times \operatorname{Ln}$ (Asset) $2-0.04 \times$ Firm age) . The larger the value of SA is, the more serious the financial constraints firms face. Treat is an indicator variable that equals 1 when an enterprise belongs to a heavily polluting industry and 0 otherwise (the guidelines for the disclosure of environmental information for listed companies issued by the Ministry of Environmental Protection point out that the iron and steel, coal, metallurgy, chemical, petrochemical, 
TABle 4: Robustness tests.

\begin{tabular}{|c|c|c|c|c|c|}
\hline & $\begin{array}{c}(1) \\
\text { Ginnovation }\end{array}$ & $\begin{array}{c}(2) \\
\text { Ginnovation }\end{array}$ & $\begin{array}{c}\text { (3) } \\
\text { Ginnovation1 }\end{array}$ & $\begin{array}{c}(4) \\
\text { Ginnovation }\end{array}$ & $\begin{array}{c}(5) \\
\text { Ginnovation }\end{array}$ \\
\hline Treat $\times$ Year2011 & $\begin{array}{c}0.0011 \\
(0.0023)\end{array}$ & & & & \\
\hline Treat $\times$ Year2012 & $\begin{array}{c}0.0012 \\
(0.0023)\end{array}$ & & & & \\
\hline Treat $\times$ Year 2013 & $\begin{array}{c}0.0031 \\
(0.0023)\end{array}$ & & & & \\
\hline Treat $\times$ Year2014 & $\begin{array}{c}0.0034 \\
(0.0023)\end{array}$ & & & & \\
\hline Treat $\times$ Year 2015 & $\begin{array}{l}0.0044^{*} \\
(0.0023)\end{array}$ & & & & \\
\hline Treat $\times$ Year2016 & $\begin{array}{c}0.0091^{* * *} \\
(0.0023)\end{array}$ & & & & \\
\hline Treat $\times$ Post & & $\begin{array}{c}0.0048^{* *} \\
(0.0019)\end{array}$ & $\begin{array}{c}0.0026^{* *} \\
(0.0010)\end{array}$ & $\begin{array}{c}0.0048^{* * *} \\
(0.0014)\end{array}$ & $\begin{array}{c}0.0028^{* *} \\
(0.0014)\end{array}$ \\
\hline AGDP & $\begin{array}{l}-0.0032 \\
(0.0035)\end{array}$ & $\begin{array}{c}0.0004 \\
(0.0050)\end{array}$ & $\begin{array}{l}-0.0032 \\
(0.0026)\end{array}$ & $\begin{array}{l}-0.0031 \\
(0.0036)\end{array}$ & $\begin{array}{c}0.0036 \\
(0.0039)\end{array}$ \\
\hline FDI & $\begin{array}{c}0.0292 \\
(0.0425)\end{array}$ & $\begin{array}{c}0.0946 \\
(0.0679)\end{array}$ & $\begin{array}{c}0.0180 \\
(0.0315)\end{array}$ & $\begin{array}{c}0.0276 \\
(0.0433)\end{array}$ & $\begin{array}{c}0.0369 \\
(0.0593)\end{array}$ \\
\hline Struct & $\begin{array}{c}0.0001 \\
(0.0002)\end{array}$ & $\begin{array}{c}0.0001 \\
(0.0002)\end{array}$ & $\begin{array}{c}0.0000 \\
(0.0001)\end{array}$ & $\begin{array}{c}0.0001 \\
(0.0002)\end{array}$ & $\begin{array}{l}-0.0001 \\
(0.0002)\end{array}$ \\
\hline Science & $\begin{array}{l}0.0016^{*} \\
(0.0010)\end{array}$ & $\begin{array}{c}0.0002 \\
(0.0012)\end{array}$ & $\begin{array}{l}0.0017^{* *} \\
(0.0007)\end{array}$ & $\begin{array}{l}0.0018^{*} \\
(0.0010)\end{array}$ & $\begin{array}{c}0.0033^{* * * *} \\
(0.0012)\end{array}$ \\
\hline Industry & $\begin{array}{c}-0.0038^{*} \\
(0.0022)\end{array}$ & $\begin{array}{c}-0.0065^{* *} \\
(0.0032)\end{array}$ & $\begin{array}{l}-0.0014 \\
(0.0017)\end{array}$ & $\begin{array}{l}-0.0037 \\
(0.0023)\end{array}$ & $\begin{array}{c}-0.0125^{* * *} \\
(0.0035)\end{array}$ \\
\hline POP & $\begin{array}{l}-0.0045 \\
(0.0068)\end{array}$ & $\begin{array}{c}0.0021 \\
(0.0105)\end{array}$ & $\begin{array}{r}-0.0085^{*} \\
(0.0051)\end{array}$ & $\begin{array}{l}-0.0042 \\
(0.0069)\end{array}$ & $\begin{array}{c}0.0126 \\
(0.0093)\end{array}$ \\
\hline PM25 & $\begin{array}{l}0.0061^{* *} \\
(0.0031)\end{array}$ & $\begin{array}{l}0.0075^{*} \\
(0.0044)\end{array}$ & $\begin{array}{c}0.0064^{* * * *} \\
(0.0023)\end{array}$ & $\begin{array}{l}0.0057^{*} \\
(0.0031)\end{array}$ & $\begin{array}{c}0.0023 \\
(0.0035)\end{array}$ \\
\hline Town & & & & $\begin{array}{c}0.0000 \\
(0.0001)\end{array}$ & \\
\hline Constant & $\begin{array}{c}0.0708 \\
(0.0581)\end{array}$ & $\begin{array}{c}0.0212 \\
(0.0785)\end{array}$ & $\begin{array}{c}0.0643 \\
(0.0430)\end{array}$ & $\begin{array}{c}0.0654 \\
(0.0590)\end{array}$ & $\begin{array}{l}-0.0410 \\
(0.0736)\end{array}$ \\
\hline $\begin{array}{l}\text { City FE } \\
\text { Year FE }\end{array}$ & Yes & $\begin{array}{l}\text { Yes } \\
\text { Yes }\end{array}$ & $\begin{array}{l}\text { Yes } \\
\text { Yes }\end{array}$ & $\begin{array}{l}\text { Yes } \\
\text { Yes }\end{array}$ & $\begin{array}{l}\text { Yes } \\
\text { Yes }\end{array}$ \\
\hline$N$ & 1798 & 1152 & 1798 & 1773 & 1021 \\
\hline$R^{2}$ & 0.0364 & 0.0231 & 0.0824 & 0.0307 & 0.0481 \\
\hline
\end{tabular}

Robust standard errors are presented in parentheses. $* * *$, and $* * *$ indicate statistical significance at the $10 \%, 5 \%$, and $1 \%$ levels, respectively.

building material, paper making, brewing, textile, tanning, and mining industries are heavily polluting industries, so the CSRC industry codes B06, B07, B08, B09, B11, C17, C18, C19, C22, C25, C26, C28, C29, C31, and C32 are the codes for heavily polluting enterprises). Post is also an indicator variable. Post is 1 after 2014 and 0 otherwise. In addition, we control for factors that affect enterprises' financial constraints [58], including the natural logarithm of total assets (Size), financial leverage (Lev), tangible assets divided by total assets (Tangi), the return on assets (ROA), and the natural logarithm of firm age. We also include a dummy variable that indicates whether a firm belongs to the government (SOE). Because ownership concentrations tend to be high and the controlling shareholder plays an important role in corporate governance [59], we control for the controlling shareholder's shareholding ratio (TOP1). Finally, we also consider CEO duality (Duality). We also include industry fixed effects $\left(\delta_{i}\right)$ to control for unobservable timeinvariant industry-specific characteristics and year fixed effects $\left(v_{t}\right)$ to control for common time trends. All variables are defined in Table 1.

First, we use model (2) to investigate the impact of the new environmental protection law on financial constraints. As shown in column 1 of Table 5, the coefficient on Treat $\times$ Post is positive and significant, suggesting that the new environmental protection law increases the financial constraints on firms in heavily polluting industries, which is consistent with the findings of Liu et al. [32], who noted that the new environmental protection law reduces the financing capacity of heavily polluting enterprises.

Then, we use model (3) to test whether enterprises' investments in green innovation can alleviate financial constraints. As shown in column 2 of Table 5, the coefficient on Treat $\times$ Post $\times$ Ginnovation is negative and significant, indicating that enterprises in high-pollution industries can alleviate their financial constraints by developing green innovation in the context of the new environmental protection law. 
TABLE 5: Economic mechanism tests.

\begin{tabular}{|c|c|c|}
\hline & $\begin{array}{l}(1) \\
\text { SA }\end{array}$ & $\begin{array}{l}(2) \\
\text { SA }\end{array}$ \\
\hline Treat $\times$ Post & $\begin{array}{c}0.0111 * * \\
(2.4287)\end{array}$ & $\begin{array}{c}0.0139 * * * \\
(2.6866)\end{array}$ \\
\hline Treat & $\begin{array}{l}0.00450 \\
(0.6760)\end{array}$ & $\begin{array}{l}-0.0107 \\
(-1.6419)\end{array}$ \\
\hline Post & $\begin{array}{c}-0.0268 * * * \\
(-5.1176)\end{array}$ & $\begin{array}{c}-0.0289 * * * \\
(-5.4169)\end{array}$ \\
\hline Size & $\begin{array}{l}-0.00540 \\
(-1.4843)\end{array}$ & $\begin{array}{c}-0.0079 * * \\
(-2.2319)\end{array}$ \\
\hline Lev & $\begin{array}{c}0.0382 * * * \\
(2.7750)\end{array}$ & $\begin{array}{c}0.0373 * * * \\
(2.7273)\end{array}$ \\
\hline Tangi & $\begin{array}{c}0.0378 * * \\
(2.4520)\end{array}$ & $\begin{array}{c}0.0340 * * \\
(2.2324)\end{array}$ \\
\hline $\mathrm{ROA}$ & $\begin{array}{c}-0.0803 * * * \\
\quad(-3.0255)\end{array}$ & $\begin{array}{c}-0.0888 * * * \\
\quad(-3.3643)\end{array}$ \\
\hline Age & $\begin{array}{c}-0.6071 * * * \\
(-70.7974)\end{array}$ & $\begin{array}{c}-0.6072 * * * \\
(-70.4597)\end{array}$ \\
\hline SOE & $\begin{array}{c}-0.0063 * * \\
(-2.2639)\end{array}$ & $\begin{array}{c}-0.0063 * * \\
(-2.2682)\end{array}$ \\
\hline TOP1 & $\begin{array}{c}0.0000 \\
(0.3619)\end{array}$ & $\begin{array}{c}0.0000 \\
(0.2161)\end{array}$ \\
\hline Duality & $\begin{array}{c}0.0102 * * * \\
(3.0259)\end{array}$ & $\begin{array}{c}0.0099 * * * \\
(2.9506)\end{array}$ \\
\hline Treat $\times$ Post $\times$ Ginnovation & & $\begin{array}{l}-0.0131 * \\
(-1.6726)\end{array}$ \\
\hline Treat $\times$ Ginnovation & & $\begin{array}{c}0.0488 * * * \\
(3.7273)\end{array}$ \\
\hline Post $\times$ Ginnovation & & $\begin{array}{c}0.0099 * * * \\
(2.9239)\end{array}$ \\
\hline Ginnovation & & $\begin{array}{c}0.0021 \\
(0.4313)\end{array}$ \\
\hline Constant & $\begin{array}{c}-1.9688 * * * \\
(-24.2725)\end{array}$ & $\begin{array}{c}-1.9114 * * * \\
(-24.2617)\end{array}$ \\
\hline Industry FE & Yes & Yes \\
\hline Year FE & Yes & Yes \\
\hline$N$ & 23186 & 23062 \\
\hline$R^{2}$ & 0.766 & 0.771 \\
\hline
\end{tabular}

Robust standard errors are presented in parentheses. $* * *$, and $* * *$ indicate statistical significance at the $10 \%, 5 \%$, and $1 \%$ levels, respectively. All variables are defined in Table 1.

In summary, the analysis suggests that the new environmental protection law can affect green innovation by changing the financial constraints that enterprises face.

\section{Further Analyses}

6.1. The Effect of Banking Competition. In the micromechanism tests, we found that the new environmental protection law affects green innovation by changing enterprises' financial constraints. Fierce banking competition reduces the market power of banks, which increases the bargaining power of enterprises and reduces the impact of the new environmental protection law on green innovation, which comes through the imposition of stronger financial constraints on enterprises in heavily polluting industries. Therefore, a lower level of banking competition can positively affect the relationship between the new environmental protection law and green innovation by increasing the market power of banks. As a result, we expect the effect of the new environmental protection law on the stimulation of green innovation to be more prominent in prefecture-level cities with lower levels of banking competition.

Data on the loan market and on deposits are not available for prefecture-level cities. Following Degryse and Ongena [60] and Chong et al. [61], we use the number of bank branches in each prefecture-level city to develop a Herfindahl-Hirschman index (HHI) to measure banking 
competition. The HHI for a city's banking sector is calculated as follows:

$$
H H I_{i, t}=\sum_{k=1}^{N}\left(\frac{\text { Branch }_{k, t}}{\text { TotalBranches }_{i, t}}\right)^{2},
$$

where Branch $_{k, t}$ is the number of branches of bank $k$ in prefecture-level city $i$ in year $t$. TotalBranches ${ }_{i, t}$ is the total number of different banks in city $i$ in year $t$. The value of the $\mathrm{HHI}$ ranges from 0 to 1 . A higher value of the $\mathrm{HHI}$ means a lower level of banking competition.

Then, we use the following model to test the impact of banking competition on the relationship between the new environmental protection law and green innovation:

$$
\begin{aligned}
& \text { Ginnovation }_{i, t}=\beta_{0}+\beta_{1} H_{H} I_{i, t} \times \text { Treat }_{i} \times \text { Post }_{t}+\beta_{2} \text { Treat }_{i} \times \text { Post }_{t}+\beta_{3} \text { Treat }_{i} \times H H I_{i, t}+\beta_{4} \text { Post }_{i} \times \text { HHI }_{i, t} \\
& +\beta_{5} H_{H I} I_{i, t}+\beta_{6} A G D P_{i, t}+\beta_{7} \times \text { Struct }_{i, t}+\beta_{8} \times F D I_{i, t}+\beta_{9} \text { Science }_{i, t}+\beta_{10} \times \text { Industr }_{i, t}+\beta_{11} \times \text { POP }_{i, t} \\
& +\beta_{12} P M 25_{i, t}+\mu_{i}+v_{t}+\varepsilon_{i, t},
\end{aligned}
$$

where $i$ and $t$ represent prefecture-level cities and years, respectively. The coefficient of interest is $\beta_{1}$. We expect $\beta_{1}$ to be positive because the larger the value of the HHI is, the lower the banking sector's competition is.

As shown in column 1 of Table 6 , the coefficient on Treat $\times$ Post $\times \mathrm{HHI}$ is positive and statistically significant at the $5 \%$ level, suggesting that the relationship between the new environmental protection law and green innovation is more prominent in prefecture-level cities with lower levels of banking competition.

6.2. The Effect of Intellectual Property Protection. Intellectual property protection is regarded as an effective incentive for innovation [37, 62]. Innovations are nonrival goods, suggesting that inventors cannot prevent others from using their inventions [37]. This means that other inventors can copy innovations and appropriate at least a portion of the profits from those innovations without $R \& D$ investments [63]. Intellectual protection provides inventors with the right to obtain monopoly profits over a certain period of time to offset the cost of R\&D investments, which can encourage innovation. Although the legal system is underdeveloped in China [64], some regions, such as Beijing,
Shanghai, and Guangdong, have better intellectual property protection. Thus, in terms of intellectual property protection, there is extensive heterogeneity. Better intellectual property protection promotes innovation, including green innovation. Therefore, we expect that the relationship between the new environmental protection law and green innovation is more prominent in prefecture-level cities with stronger intellectual property protection.

We use the natural logarithm of the number of first instances of intellectual property infringement in a province to measure intellectual property protection (IPP). This approach is taken because the legal system is underdeveloped, and the number of first instances of intellectual property infringement can reflect the level of intellectual property protection. In addition, prefecture-level cities in the same province have a similar level of intellectual property protection. Specifically, a larger number of first instances of intellectual property infringement indicate better intellectual property protection.

To examine the impact of intellectual property protection on the association between the new environmental protection law and green innovation, we use the following model:

$$
\begin{aligned}
& \text { Ginnovation }_{i, t}=\beta_{0}+\beta_{1} \text { IPP }_{i, t} \times \text { Treat }_{i} \times \text { Post }_{t}+\beta_{2} \text { Treat }_{i} \times \text { Post }_{t}+\beta_{3} \text { Treat }_{i} \times I P P_{i, t} \\
& +\beta_{4} \text { Post }_{i} \times I P P_{i, t}+\beta_{5} I P P_{i, t}+\beta_{6} A G D P_{i, t}+\beta_{7} \times \text { Struct }_{i, t}+\beta_{8} \times F D I_{i, t} \\
& +\beta_{9} \text { Science }_{i, t}+\beta_{10} \times \text { In du str } y_{i, t}+\beta_{11} \times P O P_{i, t}+\beta_{12} P M 25_{i, t}+\mu_{i}+v_{t}+\varepsilon_{i, t} \text {, }
\end{aligned}
$$

where $i$ and $t$ represent prefecture-level cities and years, respectively. The coefficient of interest is $\beta_{1}$. We expect $\beta_{1}$ to be positive.
In column 2 of Table 6 , we find that the coefficient on Treat $\times$ Post $\times$ IPP is positive and significant, indicating that the relationship between the new environmental property 
TABLE 6: Further analyses.

\begin{tabular}{|c|c|c|}
\hline & $\begin{array}{c}(1) \\
\text { Ginnovation }\end{array}$ & $\begin{array}{c}(2) \\
\text { Ginnovation }\end{array}$ \\
\hline Treat $\times$ Post $\times$ HHI & $\begin{array}{c}0.0125 * * \\
(0.0063)\end{array}$ & \\
\hline Treat $\times$ HHI & $\begin{array}{c}0.0087 * * \\
(0.0042)\end{array}$ & \\
\hline Post $\times$ HHI & $\begin{array}{c}0.0004 \\
(0.0029)\end{array}$ & \\
\hline Treat $\times$ Post $\times$ IPP & $0.0019 *$ & $(0.0010)$ \\
\hline Treat $\times$ IPP & & $\begin{array}{c}0.0007 \\
(0.0007)\end{array}$ \\
\hline Post $\times$ IPP & & $\begin{array}{c}0.0005 \\
(0.0007)\end{array}$ \\
\hline IPP & & $\begin{array}{l}-0.0002 \\
(0.0006)\end{array}$ \\
\hline HHI & $\begin{array}{l}-0.0046 \\
(0.0035)\end{array}$ & \\
\hline Treat $\times$ Post & $\begin{array}{c}0.0029 \\
(0.0020)\end{array}$ & $\begin{array}{l}-0.0105 \\
(0.0068)\end{array}$ \\
\hline AGDP & $\begin{array}{l}-0.0041 \\
(0.0035)\end{array}$ & $\begin{array}{l}-0.0044 \\
(0.0035)\end{array}$ \\
\hline FDI & $\begin{array}{c}0.0319 \\
(0.0421)\end{array}$ & $\begin{array}{c}0.0356 \\
(0.0435)\end{array}$ \\
\hline Struct & $\begin{array}{c}0.0002 \\
(0.0002)\end{array}$ & $\begin{array}{c}0.0001 \\
(0.0002)\end{array}$ \\
\hline Science & $\begin{array}{c}0.0020 * * \\
(0.0010)\end{array}$ & $\begin{array}{c}0.0011 \\
(0.0010)\end{array}$ \\
\hline Industry & $\begin{array}{c}-0.0040 * \\
(0.0022)\end{array}$ & $\begin{array}{l}-0.0033 \\
(0.0022)\end{array}$ \\
\hline POP & $\begin{array}{l}-0.0029 \\
(0.0068)\end{array}$ & $\begin{array}{l}-0.0057 \\
(0.0067)\end{array}$ \\
\hline PM25 & $\begin{array}{l}0.0056 * \\
(0.0030)\end{array}$ & $\begin{array}{c}0.0071 * * \\
(0.0031)\end{array}$ \\
\hline Constant & $\begin{array}{c}0.0670 \\
(0.0575)\end{array}$ & $\begin{array}{c}0.0864 \\
(0.0574)\end{array}$ \\
\hline City FE & Yes & Yes \\
\hline Year FE & Yes & Yes \\
\hline$N$ & 1795 & 1775 \\
\hline$R^{2}$ & 0.0390 & 0.0429 \\
\hline
\end{tabular}

Robust standard errors are presented in parentheses. $*, * *$, and $* * *$ indicate statistical significance at the $10 \%, 5 \%$, and $1 \%$ levels, respectively.

protection law and green innovation is more prominent in prefecture-level cities with stronger intellectual property protection.

\section{Conclusion}

Law is one of the most formal institutions in a country and affects the development of the economy and society. This paper investigates the impact of China's new environmental protection law on green innovation. Using a large sample of prefecture-level cities in China over the 2010-2016 period and the difference-in-differences (DID) methodology, we provide strong evidence that the new environmental protection law can promote green innovation. In addition, the positive association remains stable after testing the parallel trend assumption, changing the identification method, using an alternative measure of green innovation, controlling for the effect of urbanization, and adjusting the time window. The micromechanism analysis shows that enterprises in high-pollution industries can relieve the financial constraints aggravated by the introduction of the new environmental protection law by increasing green innovation. Further, we find that the association between the new environmental protection law and green innovation is more prominent in prefecture-level cities with a lower level of banking competition and in prefecture-level cities with stronger intellectual property protection.

The evidence provided in this paper should be of interest not only to scholars but also to policymakers. Many developing countries have achieved higher levels of economic development at the cost of air pollution, which has caused a great loss of human health. China, the largest developing country, has proven that improving legal protection of the environment is conducive to green innovation. Therefore, other developing countries seeking to coordinate economic development and environmental protection can enact stricter environmental protection laws that are in line with their own national conditions to promote green innovation and achieve sustainable development.

In addition, the government can consider limiting fierce banking competition. The new environmental protection law imposes more financial constraints on firms in heavily polluting industries, providing an impetus for these firms to engage in green innovation. Firms can alleviate financial constraints by engaging in green innovation. Therefore, banks play a crucial role in the association between the new environmental protection law and green innovation. However, stronger banking competition has a negative effect on the market power of banks, which gives firms greater access to external financing, reducing the impact of the new environmental protection law on firms' financial constraints. Thus, the government can limit the number of bank branches to lower banking competition to strengthen the effect of the new environmental protection law on green innovation.

Finally, intellectual property rights protection can provide a positive incentive for innovators to invest more resources in green innovation. Therefore, to improve the level of green innovation, the government should strengthen laws and regulations on intellectual property rights protection. Moreover, the government should invest more resources in intellectual property protection, such as employing more law enforcers and reducing the cost of intellectual property suits.

\section{Data Availability}

The data used to support the findings of this study are available from the corresponding author.

\section{Conflicts of Interest}

The authors declare that there are no conflicts of interest regarding the publication of this paper. 


\section{Acknowledgments}

This study was supported by the National Natural Science Foundation of China (grant no. 72003157) and the National Social Science Fund of China (grant no. 19ZDA074).

\section{References}

[1] G. J. He, M. Y. Fan, and M. G. Zhou, "The effect of air pollution on mortality in China: evidence from the 2008 Beijing Olympic games," Journal of Environmental Economics \& Management, vol. 79, pp. 19-39, 2016.

[2] E. Lanzi, R. Dellink, and J. Chateau, "The sectoral and regional economic consequences of outdoor air pollution to 2060," Energy Economics, vol. 71, pp. 89-113, 2018.

[3] W. Wu, W. Wang, and M. Zhang, "Using China's provincial panel data exploring the interaction between socio-economic and eco-environment system," Ecological Complexity, vol. 44, no. 2, p. 100873, 2020.

[4] W. Wu, M. Zhang, and Y. Ding, "Exploring the effect of economic and environment factors on PM2.5 concentration: a case study of the Beijing-Tianjin-Hebei region," Journal of Environmental Management, vol. 268, p. 110703, 2020.

[5] Y. Song, J. Liu, Y. Wei, and M. Zhang, "Study on the direct and indirect effectiveness of wind power policy: empirical evidence from 30 provinces in China," Renewable Energy, vol. 170, pp. 749-763, 2021.

[6] Y. Song, Z. Li, J. Liu, T. Yang, M. Zhang, and J. Pang, "The effect of environmental regulation on air quality in China: a natural experiment during the COVID-19 pandemic," Atmospheric Pollution Research, vol. 12, no. 4, pp. 21-30, 2021.

[7] Y. Song, X. Zhang, and M. Zhang, "Research on the strategic interaction of China's regional air pollution regulation: spatial interpretation of "incomplete implementation" of regulatory policies," Environmental Science and Pollution Research, vol. 27, no. 34, pp. 42557-42570, 2020.

[8] M. Zhang, X. Liu, Y. Ding, and W. Wang, "How does environmental regulation affect haze pollution governance?-An empirical test based on Chinese provincial panel data," Science of the Total Environment, vol. 695, p. 133905, 2019.

[9] M. Zhang, X. Sun, and W. Wang, "Study on the effect of environmental regulations and industrial structure on haze pollution in China from the dual perspective of independence and linkage," Journal of Cleaner Production, vol. 256, no. 1, p. 120748, 2020.

[10] E. Elahi, C. Weijun, S. K. Jha, and H. Zhang, "Estimation of realistic renewable and non-renewable energy use targets for livestock production systems utilising an artificial neural network method: a step towards livestock sustainability," Energy, vol. 183, pp. 191-204, 2019.

[11] E. Elahi, C. Weijun, H. Zhang, and M. Abid, "Use of artificial neural networks to rescue agrochemical-based health hazards: a resource optimisation method for cleaner crop production," Journal of Cleaner Production, vol. 238, p. 117900, 2019.

[12] E. Elahi, Z. Khalid, C. Weijun, and H. Zhang, "The public policy of agricultural land allotment to agrarians and its impact on crop productivity in Punjab province of Pakistan," Land Use Policy, vol. 90, p. 104324, 2020.

[13] E. Elahi, M. Abid, L. Zhang, S. ul Haq, and J. G. M. Sahito, "Agricultural advisory and financial services; farm level access, outreach and impact in a mixed cropping district of Punjab, Pakistan," Land Use Policy, vol. 71, pp. 249-260, 2018.

[14] E. Elahi, Z. Khalid, M. Z. Tauni, H. Zhang, and X. Lirong, "Extreme weather events risk to crop-production and the adaptation of innovative management strategies to mitigate the risk: a retrospective survey of rural Punjab, Pakistan," Technovation, p. 102255, 2021.

[15] E. Elahi, H. Zhang, X. Lirong, Z. Khalid, and H. Xu, "Understanding cognitive and socio-psychological factors determining farmers' intentions to use improved grassland: implications of land use policy for sustainable pasture production," Land Use Policy, vol. 102, p. 105250, 2021.

[16] B. Peng, C. Zheng, G. Wei, and E. Elahi, "The cultivation mechanism of green technology innovation in manufacturing industry: from the perspective of ecological niche," Journal of Cleaner Production, vol. 252, p. 119711, 2020.

[17] B. Peng, H. Chen, E. Elahi, and G. Wei, "Study on the spatial differentiation of environmental governance performance of Yangtze river urban agglomeration in Jiangsu province of China," Land Use Policy, vol. 99, p. 105063, 2020.

[18] B. H. Peng, G. Wei, E. Elahi, and T. R. Yu, "Regional environmental regulation efficiency: spatiotemporal characteristics and influencing factors," Environmental Science and Pollution Research International, vol. 26, no. 36, pp. 3715237161, 2019.

[19] B. Peng, Y. Wang, E. Elahi, and G. Wei, "Behavioral game and simulation analysis of extended producer responsibility system's implementation under environmental regulations," Environmental Science and Pollution Research, vol. 26, no. 17, pp. 17644-17654, 2019.

[20] B. Peng, S. Chen, E. Elahi, and A. Wan, "Can corporate environmental responsibility improve environmental performance? An inter-temporal analysis of Chinese chemical companies," Environmental Science and Pollution Research, vol. 28, no. 10, pp. 12190-12201, 2021.

[21] B. Peng, Y. Tu, E. Elahi, and G. Wei, "Extended producer responsibility and corporate performance: effects of environmental regulation and environmental strategy," Journal of Environmental Management, vol. 218, no. 15, pp. 181-189, 2018.

[22] Z. Huang, G. Liao, and Z. Li, "Loaning scale and government subsidy for promoting green innovation," Technological Forecasting and Social Change, vol. 144, pp. 148-156, 2019.

[23] S. K. Taklo, H. S. Tooranloo, and Z. S. Parizi, "Green innovation: a systematic literature review," Journal of Cleaner Production, vol. 279, p. 122474, 2021.

[24] S. B. Lai, C. T. Wen, and Y. S. Chen, The Exploration of the Relationship between the Environmental Pressure and the Corporate Competitive Advantage, National Chiao Tung University, Hsinchu, Taiwan, 2003.

[25] H. Baumann, F. Boons, and A. Bragd, "Mapping the green product development field: engineering, policy and business perspectives," Journal of Cleaner Production, vol. 10, no. 5, pp. 409-425, 2002.

[26] V. Costantini and M. Mazzanti, "On the green and innovative side of trade competitiveness? the impact of environmental policies and innovation on eu exports," Research Policy, vol. 41, no. 1, pp. 132-153, 2012.

[27] C. Shen, S. Li, X. Wang, and Z. Liao, "The effect of environmental policy tools on regional green innovation: evidence from China," Journal of Cleaner Production, vol. 254, p. 120122, 2020.

[28] R. Calel and D.. Antoine, "Environmental policy and directed technological change: evidence from the European carbon market," Review of Economics \& Statistics, vol. 98, no. 1, pp. 551-574, 2012.

[29] J. Cui, J. Zhang, and Y. Zheng, "Carbon pricing induces innovation: evidence from China's regional carbon market pilots," AEA Papers and Proceedings, vol. 108, pp. 1-5, 2018. 
[30] B. Zhang, C. Cao, J. Gu, and T. Liu, "A new environmental protection law, many old problems? challenges to environmental governance in China," Journal of Environmental Law, vol. 28, no. 2, pp. 325-335, 2016.

[31] L. Zhang, G. He, and A. P. J. Mol, "China's new environmental protection law: a game changer?," Environmental Development, vol. 13, pp. 1-3, 2015.

[32] X. Liu, E. Wang, and D. Cai, "Environmental regulation and corporate financing-quasi-natural experiment evidence from China," Sustainability, vol. 10, no. 11, p. 4028, 2018.

[33] J. Chen, J. Huang, X. Huang, S. Sun, Y. Hao, and H. Wu, "How does new environmental law affect public environmental protection activities in China? evidence from structural equation model analysis on legal cognition," Science of The Total Environment, vol. 714, p. 136558, 2020.

[34] W. Cai and P. Ye, "How does environmental regulation influence enterprises' total factor productivity? a quasi-natural experiment based on China's new environmental protection law," Journal of Cleaner Production, vol. 276, p. 124105, 2020.

[35] S. Chava, A. Oettl, A. Subramanian, and K. V. Subramanian, "Banking deregulation and innovation," Journal of Financial Economics, vol. 109, no. 3, pp. 759-774, 2013.

[36] J. Cornaggia, Y. Mao, X. Tian, and B. Wolfe, "Does banking competition affect innovation?," Journal of Financial Economics, vol. 115, no. 1, pp. 189-209, 2015.

[37] S. Kanwar and R. E. Evanson, "Does intellectual property protection spur technological change?," Oxford Economic Papers, vol. 55, no. 2, pp. 235-264, 2003.

[38] H. Sun, B. K. Edziah, C. Sun, and A. K. Kporsu, "Institutional quality, green innovation and energy efficiency," Energy Policy, vol. 135, p. 111002, 2019.

[39] J. W. Huang and Y. H. Li, "Green innovation and performance: the view of organizational capability and social reciprocity," Journal of Business Ethics, vol. 145, no. 2, pp. 1-16, 2017.

[40] R. Kunapatarawong and E. Martínez-Ros, "Towards green growth: how does green innovation affect employment?," Research Policy, vol. 45, no. 6, pp. 1218-1232, 2016.

[41] Y.-S. Chen, "The driver of green innovation and green imagegreen core competence," Journal of Business Ethics, vol. 81, no. 3, pp. 531-543, 2008.

[42] D. Zhang, Z. Rong, and Q. Ji, "Green innovation and firm performance: evidence from listed companies in China," Resources, Conservation and Recycling, vol. 144, pp. 48-55, 2019.

[43] M. Abdullah, S. Zailani, M. Iranmanesh, and K. Jayaraman, "Barriers to green innovation initiatives among manufacturers: the Malaysian case," Review of Managerial Science, vol. 10, no. 4, pp. 1-27, 2016.

[44] H. Lin, S. X. Zeng, H. Y. Ma, G. Y. Qi, and V. W. Y. Tam, "Can political capital drive corporate green innovation? lessons from China," Journal of Cleaner Production, vol. 64, no. 1, pp. 63-72, 2014.

[45] M. D. Amore and M. Bennedsen, "Corporate governance and green innovation," Journal of Environmental Economics and Management, vol. 75, pp. 54-72, 2016.

[46] A. Demirgüç-Kunt and R. Levine, Financial Structure and Economic Growth: Cross-Country Comparisons of Banks, Markets, and Development, The MIT Press, Cambridge, MA, USA, 2001.

[47] F. Leon, "Does bank competition alleviate credit constraints in developing countries?," Journal of Banking \& Finance, vol. 57, pp. 130-142, 2015.
[48] I. Love and M. Martínez Pería, How Bank Competition Affects Firms' Access to Finance, pp. 413-448, World Bank Economic Review, Washington, DC, USA, 2015.

[49] P. Liu and H. Li, "Does bank competition spur firm innovation?," Journal of Applied Economics, vol. 23, no. 1, pp. 519-538, 2020.

[50] P. Dobers and R. Wolff, "Competing with ?soft? issues-from managing the environment to sustainable business strategies," Business Strategy and the Environment, vol. 9, no. 3, pp. 143-150, 2000.

[51] J. Liu, R. F. Stambaugh, and Y. Yuan, "Size and value in China," Journal of Financial Economics, vol. 134, no. 1, pp. 48-69, 2019.

[52] D. Li, Y. Zhao, L. Zhang, X. Chen, and C. Cao, "Impact of quality management on green innovation," Journal of Cleaner Production, vol. 170, no. 1, pp. 462-470, 2018.

[53] Z. Griliches, A. Pakes, and B. Hall, The Value of Patents as Indicators of Inventive Activity, Cambridge University Press, Cambridge, UK, 1988.

[54] L. Xu, C.-F. Yu, and R. Zurbruegg, "The benefit of being a local leader: evidence from firm-specific stock price crash risk," Journal of Corporate Finance, vol. 65, p. 101752, 2020.

[55] H. Li, J. Wu, and Z. Lu, "Bank diversity and SME innovation: evidence from China," International Journal of Bank Marketing, vol. 38, no. 2, pp. 265-282, 2019.

[56] Y. C. Bian, L. H. Wu, and J. H. J. Bai, "Does high-speed rail improve regional innovation in China?," Journal of Financial Research, vol. 6, pp. 132-149, 2019, (in Chinese).

[57] C. J. Hadlock and J. R. Pierce, "New evidence on measuring financial constraints: moving beyond the KZ index," Review of Financial Studies, vol. 23, no. 5, pp. 1909-1940, 2010.

[58] R. Álvarez and M. J. Bertin, "Banking competition and firmlevel financial constraints in Latin America," Emerging Markets Review, vol. 28, pp. 89-104, 2016.

[59] F. Jiang and K. A. Kim, "Corporate governance in China: a modern perspective," Journal of Corporate Finance, vol. 32, pp. 190-216, 2015.

[60] H. Degryse and S. Ongena, "The impact of competition on bank orientation," Journal of Financial Intermediation, vol. 16, no. 3, pp. 399-424, 2007.

[61] T. T.-L. Chong, L. Lu, and S. Ongena, "Does banking competition alleviate or worsen credit constraints faced by small- and medium-sized enterprises? evidence from China," Journal of Banking \& Finance, vol. 37, no. 9, pp. 3412-3424, 2013.

[62] L. H. Fang, J. Lerner, and C. Wu, "Intellectual property rights protection, ownership, and innovation: evidence from China," The Review of Financial Studies, vol. 30, no. 7, pp. 2446-2477, 2017.

[63] B. L. Smith and S. O. Mann, "Innovation and intellectual property protection in the software industry: an emerging role for patents?," University of Chicago Law Review, vol. 71, no. 1, pp. 241-264, 2004.

[64] F. Allen, J. Qian, and M. Qian, "Law, finance, and economic growth in China," Journal of Financial Economics, vol. 77, no. 1, pp. 57-116, 2005. 